\title{
PERLAKUAN TERHADAP ANAK DI DALAM PERUNDANG-UNDANGAN DI INDONESIA \\ (Telaah Kritis Pasal 7 Ayat 1 UU No. 1 Tahun 1974 \\ Tentag Batas Umur Melangsungkan Perkawinan)
}

\author{
Sofia Hardani \\ Dosen Fakultas Syari'ah \& Hukum UIN Suska Riau \\ Email: sofia.hardani@yahoo.com
}

\begin{abstract}
In article 7, paragraph (1) of Law No. 1 of 1974 on marriage mentioned that the maturity of a child is if the man was 21 years old and 18 year old girl. In article 7, paragraph (1) of Law No. 1 of 1974 on marriage states that marriage is only allowed if a man has reached the age of 19 years and women have attained the age of 16 years. That is, the law allows minors to enter into marriage. On the other hand, the law looks acknowledge a violation of the provisions of the age and maturity limits candidates to enter into marriage. It is accommodated in article 7, paragraph (2) of Law No. 1 1974, that court or other officials appointed by the parents of the male and female can give dispensation to the minors to enter into marriage. Inconsistency Law 11974 about the age limit can be interpreted as accommodate marriage of underage marriage. Moreover, in Article 7 of the law as well as in his explanation did not mention the reasons that can be used as the basis of given dispensation, so that everyone can easily obtain it. Law's provision is very loose, but when viewed from various aspects, a lot of harm caused by the underage marriage, particularly for women.
\end{abstract}

Keywords: Law, Marriage, Maturity, Children

Abstrak: Di dalam pasal 7 ayat (1) Undang-undang Nomor 1 tahun 1974 tentang perkawinan disebutkan bahwa kedewasaan seorang anak adalah jika laki-laki berumur 21 tahun dan perempuan berumur 18 tahun. Di dalam pasal 7 ayat (1) Undang-undang Nomor 1 tahun 1974 tentang perkawinan disebutkan bahwa perkawinan hanya diizinkan jika pria sudah mencapai umur 19 tahun dan wanita telah mencapai umur 16 tahun. Artinya, undang-undang ini membolehkan anak yang belum dewasa untuk melangsungkan perkawinan. Di sisi lain, undang-undang terlihat mengakui pelanggaran terhadap ketentuan batas umur dan kematangan calon untuk melangsungkan perkawinan. Hal ini diakomodir dalam pasal 7 ayat (2) UU No. 1 tahun 1974, bahwa pengadilan ataupun pejabat lain yang ditunjuk oleh kedua orang tua dari pihak laki-laki maupun perempuan dapat memberikan dispensasi kepada anak di bawah umur untuk melangsungkan perkawinan. Ketidakkonsistenan UU No. 1 tahun 1974 tentang batas umur perkawinan dapat dimaknai sebagai akomodisasi perkawinan di bawah umur.Apalagi di dalam pasal 7 UU tersebut maupun dalam penjelasannya tidak disebutkan alasan yang dapat dijadikan dasar diberikan dispensasi, sehingga setiap orang dapat dengan mudah memperolehnya.Ketetapan undang-undang sangat longgar, padahal jika ditinjau dari berbagai aspek, banyak kemudharatan yang ditimbulkan akibat perkawinan anak di bawah umur, terutama bagi perempuan.

Keywords: Undang-undang, Perkawinan, Kedewasaan, Anak

\section{PENDAHULUAN}

Menurut pasal 1 ayat (3) UUD 1945 perubahan ketiga, negara Indonesia adalah negara hukum. Dengan dimasukkannya pasal ini ke dalam bagian UUD 1945 menunjukkan bahwa penegakan keadilan di Indonesia merupakan amanat negara yang harus dilaksanakan.

Sebagai negara hukum, Indonesia sudah melakukan pembangunan hukum 
sejak lama.Akan tetapi, sampai saat ini, belum dilakukan evaluasi secara mendasar dan menyeluruh terhadap model hukum dan perundang-undangan yang dibentuk sebagai sarana pembaharuan masyarakat dalam menciptakan keadilan serta kepastian hukum.Akibatnya, hukum dan perundangundangan yang dihasilkan lebih banyak berjalan tidak efektif.Apalagi jika disesuaikan dengan dinamika masyarakat Indonesia selama lebih dari setengah abad sejak zaman proklamasi kemerdekaan. ${ }^{1}$

Sebagai patron bagi pembuatan peraturan perundang-undangan yang akan terus dibentuk untuk menjawab kebutuhan rasa keadilan masyarakat, pemerintah menetapkan Undang-Undang No. 12 tahun 2011 tentang Pembentukan Peraturan Perundang-undangan. Undang-undang ini sesungguhnya hadir sebagai penyempurna bagi Undang-Undang No. 10 tahun 2004 yang dianggap masih terdapat kekurangankekurangan.

Akan tetapi, banyak peraturan perundang-undangan yang dibuat sejak lama sebelum patron diatas diberlakukan.Salah satunya, yang banyak mendapat sorotan akhir-akhir ini adalah Undang-Undang nomor 1 tahun 1974 tentang Perkawinan. Undang-undang ini belakangan banyak mendapat kritikan dengan berbagai alasan, antara lain karena diantara pasal-pasalnya terdapat pasal-pasal yang dianggap tidak memenuhi unsur keadilan, khususnya bagi kaum perempuan.
Komisi Nasional Anti Kekerasan Terhadap Perempuan (Komnas Perempuan) bersama-sama sejumlah organisasi gerakan perempuan pernah mengajukan revisi terhadap UU Perkawinan. Beberapa permasalahan pokok yang diusulkan untuk direvisi antara lain; (1) Pendewasaan usia perkawinan di atas 18 tahun, dengan tidak membedakan batas minimal usia perkawinan bagi perempuan dan laki-laki; (2) Prinsip non diskriminasi dalam pencatatan perkawinan, di unit-unit di bawah naungan Departemen Agama; (3) Prinsip non diskriminasi juga diterapkan terhadap hak dan kewajiban bagi perempuan dan laki-laki; (4) Hak dan status anak yang dilahirkan di luar hubungan pernikahan tetap memiliki hak dan status yang sama dengan anak yang dilahirkan dalam ikatan perkawinan secara perdata, sesuai UU No. 23 tahun 2002 pasal 7 ayat (1) menyebutkan "Setiap anak berhak untuk mengetahui orang tuanya, dibesarkan, dan diasuh oleh orang tuanya sendiri."

Terlepas dari pro-kontra dan alasan pengusulan perubahan seperti yang dikemukakan diatas, di dalam UU no. 1 tahun 1974 memang termuat aturan-aturan yang tidak sesuai dengan tujuan dibentuknya undang-undang ini. Disamping ketidaktegasan undang-undang tentang batas usia perkawinan, problematika aturan pencatatan perkawinan, aturan putusnya perkawinan, aturan tentang hak dan kewajiban suami istri, masalah wali nikah, dan beberapa masalah lainnya, undang- 
undang ini tidak mengatur sanksi terhadap pelanggarannya.

Tulisan ini akan membahas tentang batas minimal usia untuk melangsungkan perkawinan, sebagaimana diatur dalam pasal 7 ayat 1 UU no. 1 tahun 1974. Bagaimana sesungguhnya undang-undang ini memandang konsep "kedewasaan" untuk dapat melangsungkan perkawinan.Apa saja permasalahan yang terjadi terkait aturan undang-undang ini, baik ditinjau dari aspek Undang-undang N0. 23 tahun 2002 tentang perlindungan anak, dan dari aspek medis, serta bagaimana solusi hukum untuk kedepannya.

\section{PEMBAHASAN}

1. Landasan Historis Pembentukan UU No. 1 tahun 1974 tentang Perkawinan

Untuk menjawab permasalahan diatas perlu ditinjau landasan historis pembentukan UU No. 1 tahun 1974 tentang Perkawinan dan relevansinya dengan kondisi masyarakat setelah diberlakukannya undang-undang ini.

Sebelum Undang-Undang Nomor 1 tahun 1974 tentang Perkawinan lahir, umat Islam di Indonesia menggunakan hukum Islam sebagai pedoman hukum perkawinannya. Hukum Islam yang telah diresepsi ke dalam hukum adat mendapatkan pengakuan dari Indische Staats Regeling (ISR), khususnya pasal 163, yang membedakan tiga golongan penduduk, yaitu; 2 a) Golongan Eropa (termasuk Jepang); b) Golongan pribumi (orang
Indonesia asli) dan; c) Golongan Timur Asing. Menurut ISR, bagi golongan pribumi yang beragama Islam berlaku hukum adatnya.

Bermula dari kesadaran kaum perempuan Islam akan hak-haknya yang merasa dikebiri oleh dominasi pemahaman fikih klasik atau konvensional yang telah mendapat pengakuan hukum dalam ISR, kaum perempuan merefleksikan hal tersebut dalam pertemuan-pertemuan yang kelak menjadi embrio lahirnya Undang-Undang Perkawinan. Arso Sosroatmojo mencatat ${ }^{3}$ sejak Kongres Perempuan Indonesia pada tahun 1928, diadakan forum yang membahas permasalahan-permasalahan yang terjadi dalam perkawinan di kalangan umat Islam, seperti perkawinan paksa, perkawinan anak di bawah umur, poligami dan talak yang sewenangwenang.Berdasarkan hal-hal tersebut, kaum perempuan mendesak untuk dibentuknya suatu perundang-undangan yang dapat melindungi kaum perempuan dalam perkawinan, yang hak-hak dan kewajibannya tidak diatur dalam hukum tertulis. Hukum perkawinan orang Indonesia asli yang beragama Islam tercantum dalam kitab-kitab fikih, sementara menurut sistem hukum yang berlaku, hal tersebut tidak dapat digolongkan kedalam kategori "hukum tertulis" karena tidak tertulis di dalam peraturan perundang-undangan. ${ }^{4}$

Hukum tertulis yang dimaksud jelas hukum positif yang dapat diberlakukan dan diterapkan secara pasti, terutama bagi hakim 
yang menyelesaikan perkara, juga sebagai pedoman masyarakat luas dalam melakukan tindakan hukum, sehingga jika terjadi pelanggaran hak orang lain dapat dilakukan tindakan hukum yang sifatnya mengikat secara pasti.

Setelah Indonesia merdeka, langkah perbaikan yang dilakukan oleh pemerintah antara lain mengeluarkan Undang-undang Pencatatan Nikah, Talak dan Rujuk (NTR) pada tahun 1946. Disusul dengan Peraturan Mentri Agama mengenai wali hakim dan tata carapemeriksaan perkara fasid nikah, talak dan rujuk di Pengadilan Agama. Namun demikian, tuntutan untuk perbaikan belumlah terpenuhi, karena undang-undang dan peraturan-peraturan tersebut hanya terkait dengan masalah formal belaka.Hukum materilnya, yaitu undangundang yang mengatur perkawinan itu sendiri belum ada.

Pada akhir tahun 1950, berdasarkan Surat Keputusan Menteri Agama No.B/2/4299 tertanggal 1 Oktober 1950 dibentuk Panitia Penyelidik Peraturan dan Hukum Perkawinan, Talak dan Rujuk bagi umat Islam. Sementara itu, berbagai organisasi terus menerus mendesak Pemerintah dan DPR agar secepat mungkin merampungkan penggarapan Rancangan Undang-undang (RUU) hukum perkawinan untuk segera diundangkan. Usaha umat Islam $^{5}$ untuk memperjuangkan RUU tentang Pokok-Pokok Perkawinan Umat Islam tersebut tidak berhasil, dan DPR hasil pemilihan umum tahun 1971 mengembalikan RUU tersebut ke pemerintah.

Segala upaya telah dikerahkan untuk menghasilkan undang-undang perkawinan yang sesuai untuk umat Islam. Menurut Arso Sosroatmojo, ${ }^{6}$ pada rentang waktu tahun 1972-1973 berbagai organisasi gabungan terus memperjuangkan lahirnya undangundang tersebut. Simposium Ikatan Sarjana Wanita Indonesia (ISWI) pada tanggal 1972 menyarankan agar PP ISWI memperjuangkan Undang-Undang Perkawinan. Selain itu, Badan Musyawarah Organisasi-Organisasi Wanita Islam Indonesia pada tanggal 22 Februari 1972 salah satunya menghasilkan keputusan untuk mendesak pemerintah agar mengajukan kembali RUU tentang PokokPokok Perkawinan Umat Islam dan RUU tentang Ketentuan Pokok-Pokok Perkawinan. Selanjutnya, organisasi Mahasiswa yang ikut ambil bagian dalam perjuangan RUU Perkawinan Umat Islam yaitu Himpunan Mahasiswa Islam (HMI) yang telah mengadakan diskusi panel pada tanggal 11 Februari 1973.

Akhirnya setelah bekerja keras, tanggal 31 Juli 1973 pemerintah menyampaikan RUU tentang Perkawinan yang baru kepada DPR, yang terdiri dari 15 bab dan 73 pasal. RUU ini mempunyai tiga tujuan, yaitu (a) memberikan kepastian hukum bagi masalah-masalah perkawinan, sebab sebelum adanya undang-undang maka perkawinan hanya bersifat judge made law, (b) 
untuk melindungi hak-hak kaum perempuan sekaligus memenuhi keinginan dan harapan kaum perempuan serta (c) menciptakan undang-undang yang sesuai dengan tuntutan zaman.

Setelah melalui proses yang cukup panjang, setelah mendapat persetujuan dari DPR, Pemerintah mengundangkan UndangUndang Perkawinan pada tanggal 2 Januari 10974 dalam Lembaran Negara Nomor 1 tahun 1974. Pada tanggal 1 April 1975, dikeluarkan Peraturan Pemerintah No. 9 tahun 1975 yang memuat peraturan pelaksanaan UU Perkawinan tersebut. Pada tanggal 1 Oktober 1975, UU No. 1 tahun 1974 sudah dapat berjalan dengan efektif.7

Disahkannya UU No. 1 Tahun 1974 tentang perkawinan memang menjadi angin segar dan oase di tengah gurun protes beberapa organisasi besar terhadap pemerintah, khususnya aktivis perempuan Indonesia dari kalangan muslim, yang merasa hak-haknya terkebiri oleh pemahaman konvensional tentang peran dan kedudukan perempuan dalam keluarga dan masyarakat serta pemahaman fikih klasik yang cenderung patriarkhis. Reaksi atas keburukan-keburukan yang terjadi dalam perkawinan 8 di kalangan umat muslim seperti perkawinan di bawah umur, kawin paksa, talak serampangan ${ }^{9}$ dan sebagainya, mendapatkan tanggapan positif dari pemegang kebijakan pada waktu itu dengan lahirnya undang-undang tersebut.
Sudah hampir setengah abad UU No. 1 Tahun 1974 tentang perkawinan tersebut berlaku bagi seluruh warga negara Indonesia. Hanya ada beberapa perundangundangan dan peraturan yang dikeluarkan setelahnya, seperti UU No. 10 tahun 1983 tentang izin perkawinan dan perceraian bagi pegawai negeri sipil dan Inpres No. 1 Tahun 1991 tentang Kompilasi Hukum Islam, yang keduanya hanya merupakan catatan kaki dan pelengkap dari UU No. 1 Tahun 1974.

Jika ditelaah pasal demi pasal, di dalam UU No. 1 tahun 1974 tersebut ditemukan beberapa pasal yang perlu mendapat perhatian, kaitannya dengan jaminan terhadap semua unsur yang berkaitan dengan perkawinan dan keluarga, terutama kaum perempuan, jika dikontekstualisasikan dan dilihat relevansinya dengan isu-isu gobal yang beredar dan kebutuhan umat muslim akan peraturan yang mengakomodasi dan tidak mengekang kebutuhan umat. Demikian juga jika ditinjau dari aspek historis dibuatnya undang-undang ini.

\section{Konsep "kedewasaan" untuk melangsungkan perkawinan menurut UU No. 1 tahun 1974}

Di dalam Bab I pasal 1 UU No. 1 Tahun 1974 disebutkan tentang definisi dan tujuan perkawinan, yaitu "perkawinan adalah ikatan lahir batin antara seorang pria dengan seorang wanita sebagai suami istri dengan tujuan membentuk keluarga atau 
rumah tangga yang bahagia dan kekal berdasarkan Ketuhanan Yang Maha Esa."10

Banyak faktor yang harus diperhatikan untuk dapat terwujudnya keluarga yang bahagia dan kekal tersebut, antara lain adalah kesiapan dan kematangan calon suami maupun istri untuk berumah tangga. Kesiapan dan kemantangan ini mencakup fisik, mental, dan material.

Sehubungan dengan hal tersebut, Undang-Undang Nomor 1 tahun 1974 tentang Perkawinan di Indonesia telah merumuskan prinsip-prinsip perkawinan, diantaranya adalah calon suami dan calon istri haruslah telah "masak jiwa raganya" untuk dapat melangsungkan perkawinan agar dapat mewujudkan tujuan perkawinan dengan baik tanpa berpikir pada perceraian dan mendapat keturunan yang baik dan sehat. 11

Sejalan dengan prinsip perkawinan tersebut, pasal 7 ayat (1) undang-undang ini menyebutkan bahwa "perkawinan hanya diizinkan jika pihak pria sudah mencapai umur 19 tahun (sembilan belas tahun) dan pihak wanita telah mencapai umur 16 (enam belas) tahun.Ketentuan batas umur ini, seperti disebutkan di dalam Kompilasi Hukum Islam pasal 15 ayat (1),12 didasarkan pada pertimbangan kemaslahatan keluarga dan rumah tangga perkawinan. ${ }^{13}$ Untuk itulah harus dicegah adanya perkawinan antara calon suami dan calon istri yang masih dibawah umur. ${ }^{14}$
Kebijakan pemerintah dalam menetapkan batas minimal usia pernikahan ini tentunya melalui proses dan berbagai pertimbangan. Hal ini dimaksudkan agar kedua belah pihak benar-benar siap dan matang dari segi fisik, psikis, dan mental untuk melangsungkan perkawinan. ${ }^{15}$ Kedewasaan seorang anak menurut undang-undang ini jika laki-laki berumur 21 tahun dan perempuan berumur 18 tahun.Artinya, undang-undang ini membolehkan anak yang belum dewasa (berumur dibawah 21 tahun bagi laki-laki dan dibawah 18 tahun bagi perempuan) untuk melangsungkan perkawinan.

Di sisi lain, undang-undang terlihat mengakui pelanggaran terhadap ketentuan batas umur dan kematangan calon untuk melangsungkan perkawinan. Hal ini diakomodir dalam pasal 7 ayat (2) UU No. 1 tahun 1974, bahwa pengadilan ataupun pejabat lain yang ditunjuk oleh kedua orang tua dari pihak laki-laki maupun perempuan dapat memberikan dispensasi kepada anak di bawah umur untuk melangsungkan perkawinan.

Ketidakkonsistenan UU No. 1 tahun 1974 tentang batas umur perkawinan sangat memicu terjadinya perkawinan di bawah umur.Apalagi di dalam pasal 7 UU tersebut maupun dalam penjelasannya tidak disebutkan suatu alasan yang dapat dijadikan dasar dapatnya diberikan dispensasi, sehingga setiap orang dapat dengan mudah memperoleh dispensasi 
tersebut. 16 Dengan demikian, ketetapan undang-undang tersebut menjadi sangat bersifat longgar dan tidak terlalu mengikat, karena perkawinan dibawah batas usia minimal tersebut dapat disahkan oleh undang-undang.

Selanjutnya, undang-undang menyebutkan bahwa jika seorang anak belum mencapai usia 21 tahun untuk melangsungkan perkawinan ia harus mendapat izin dari kedua orang tuanya (pasal 6 ayat 2). Dalam hal salah seorang dari orang tua telah meninggal dunia atau tidak mampu menyatakan pendapatnya, maka izin cukup diperoleh dari orang tua yang mampu menyatakan kehendaknya (pasal 6 ayat 3). ${ }^{17}$ Apabila izin tidak didapat dari pihak orang tua, Pengadilan dapat memberikan izin berdasarkan atas permintaan orangorang yang hendak melangsungkan perkawinan. ${ }^{18}$

Ketentuan terakhir ini, juga terlihat cukup longgar dan sangat berpotensi untuk diabaikan, karena jika orang tua tidak dapat memberikan izin, pengadilanpun dapat menggantikan peran mereka.

\section{Realitas penyimpangan pasal 7 ayat (1)}

\section{UU No. 1 tahun 1974 di Indonesia}

Di tengah kontroversi tentang ketentuan batas umur perkawinan dan kedewasaan yang terdapat dalam UU No. 1 tahun 1974, perkawinan anak di bawah umur di Indonesia masih banyak terjadi karena tradisi di dalam suatu komunitas dan pengamalan terhadap "ketentuan agama", tanpa memandang aspek maslahah dan mafsadah.

Di dalam masyarakat Indonesia, fenomena pernikahan anak dibawah umur bukanlah hal yang baru, baik di kota besar maupun di daerah pedesaan. Banyak alasan yang menjadi penyebabnya, seperti persoalan ekonomi, rendahnya pendidikan, pemahaman budaya dan nilai-nilai agama tertentu, atau hamil terlebih dahulu sebelum menikah.Konon para orang tua zaman dulu banyak yang menikahi gadis di bawah umur. Bahkan - pada zaman dahulu - pernikahan di usia "matang" akan menimbulkan preseden buruk di mata masyarakat. Perempuan yang tidak segera menikah justru akan mendapat tanggapan miring atau lazim disebut perawan tua.

Di Jawa dan Aceh, adalah suatu kelumrahan terjadinya suatu perkawinan seorang perempuan yang belum mencapai usia 15 tahun, tetapi mereka belum boleh hidup bersama sebagai suami istri. Harus ditangguhkan dulu sampai kedua pihak mencapai usia yang pantas. Di Jawa, perkawinan dengan corak demikian disebut dengan "gantung nikah". ${ }^{19}$

Akan tetapi, seiring perkembangan zaman, pada masa sekarang image sebagian masyarakat justru sebaliknya. Arus globalisasi yang melaju dengan cepat mengubah sikap dan cara pandang masyarakat; perempuan yang menikah di usia muda dianggap sebagai sesuatu hal 
yang tidak pantas. Bahkan lebih jauh lagi, hal itu dianggap menghancurkan masa depan perempuan, memberangus kreativitasnya, serta mencegah perempuan untuk mendapatkan pengetahuan dan wawasan yang lebih luas. Selanjutnya, realitas tentang pernikahan anak di bawah umur menjadi sesuatu yang absurd.

Pro-kontra dari berbagai sudut pandang bermunculan, baik sudut pandang agama Islam, Undang-Undang Perlindungan Anak, Undang-Undang Perkawinan hingga Konvensi PBB tentang Hak Anak. ${ }^{20}$ Pada umumnya, komentar dari berbagai kalangan tersebut bernilai negatif, karena disinyalir bahwa pernikahan dini menyebabkan Angka Kematian Ibu melahirkan (AKI) meningkat secara signifikan.Pernikahan dini juga berkorelasi positif dengan meningkatnya angka kehamilan yang tidak diinginkan, aborsi, perdagangan manusia (trafficking), jumlah anak telantar, meningkatnya angka perceraian dan pengangguran, 21 serta meningkatnya populasi penduduk. Siti Musdah Mulia, lebih keras menyatakan bahwa pernikahan anak dibawah umur merupakan bentuk pelanggaran Hak Asasi Manusia, khususnya hak kesehatan reproduksi, dan yang paling penting pernikahan tersebut bertentangan dengan esensi ajaran agama yang intinya menghargai manusia dan kemanusiaan. ${ }^{22}$

Pada awal tahun 2008, tim PKPA (Pusat Kajian dan Perlindungan Anak) melakukan penelitian tentang kekerasan terhadap perempuan dan pernikahan dini di Kabupaten Nias. Berdasarkan hasil penelitian, diperoleh angka pernikahan antara usia 13-18 tahun sekitar 9,4\% dari 218 responden perempuan yang telah menikah dan akan menikah. Angka pernikahan di usia muda bagi anak perempuan $3 x$ lebih besar dibanding dengan anak laki-laki. ${ }^{23}$

Realitas selanjutnya, berdasarkan data dari Badan Pusat Statistik (BPS) pada tahun 2002, di Indonesia terdapat 34,2 \% perempuan menikah di bawah usia 15 tahun dan $11,9 \%$ laki-laki menikah dibawah usia 21 tahun. Hasil penelitian seorang dokter spesialis anak mengungkapkan, bahwa di wilayah Pantura (Jawa), sebanyak 42,8 \% responden dari kasus yang diteliti menikah di bawah usia 15 tahun. Dari total perkawinan di seluruh Indonesia, sekitar 34\% melanggar Undang-Undang Perkawinan No.1/1974..$^{24}$

Informasi di atas diperkuat lagi dengan data-data kasus yang dilansir setiap tahunnya oleh lembaga-lembaga pemerhati masalah anak dan perempuan serta hasilhasil penelitian dan survey. Misalnya, laporan Into A New World: Young Women's Sexual and Reproductive Lives yang didukung oleh The William H. Gates Foundation pada tahun 1998 telah mengungkapkan bahwa usia perempuan pertama kali melahirkan di Indonesia antara usia $13 \mathrm{~s} / \mathrm{d} 18$ tahun mencapai $18 \%$, dan pernikahan di bawah usia 18 tahun mencapai $49 \%$ pada tahun 
1998. Saat sekarang ini kondisinya tidak jauh berbeda. ${ }^{25}$

Di kota Malang menurut catatan kantor Pengadilan Agama (PA) Kota Malang tahun 2008, angka pernikahan di bawah usia 15 tahun meningkat $500 \%$ dibanding tahun 2007. Hingga September tahun 2008, tercatat 10 kasus pernikahan yang usia pengantin perempuannya masih di bawah 15 tahun. ${ }^{26}$

Fenomena pernikahan dini di daerah lainnya tidak jauh berbeda, mengingat fakta perilaku seksual remaja yang melakukan seks pra-nikah sering berujung pada pernikahan usia muda, serta kultur masyarakat Indonesia yang masih memposisikan anak perempuan sebagai warga kelas dua dan ingin mempercepat perkawinan dengan berbagai alasan; alasan ekonomi, sosial, anggapan pendidikan tinggi tidak penting bagi anak perempuan, dan stigma negatif terhadap status perawan tua.

Berdasarkan hasil kajian dan laporan kasus-kasus KDRT, kekerasan terhadap perempuan dan kekerasan terhadap anak, diskursus dan penelitian yang dilakukan oleh PKPA tahun 2008, sebagian besar masyarakat Indonesia masih menganut kultur yang memandang hal yang wajar jika pernikahan dilakukan pada usia anak-anak. Ada beberapa faktor yang menyebabkannya, antara lain:27

a. Pandangan tentang "kedewasaan" seseorang yang dilihat dari perspektif ekonomi. Ketika seseorang telah mampu menghasilkan uang atau telah terjun ke sektor pekerjaan produktif telah dipandang dewasa dan dapat melangsungkan perkawinan, meskipun usia mereka masih anak-anak.

b. Kedewasaan seseorang yang dilihat dari perubahan-perubahan secara fisik, misalnya menstruasi bagi anak perempuan dan mimpi basah bagi anak laki-laki, diikuti dengan perubahan terhadap organ-organ reproduksi.

c. Terjadinya kehamilan di luar nikah, maka menikah adalah solusi yang diambil oleh keluarga dan masyarakat untuk menutupi aib dan menyelamatkan status anak pasca kelahiran.

d. Korban perkawinan di bawah umur lebih banyak anak perempuan karena kemandirian secara ekonomi, status pendidikan dan kapasitas bahwa perempuan bukan hal penting bagi keluarga. Karena perempuan sebagai istri segala kebutuhan dan hak-hak individualnya akan menjadi tanggung jawab suami.

e. Tidak adanya sanksi pidana terhadap pelanggaran Undang-undang Perkawinan, menyebabkan pihak-pihak yang memaksa pernikahan di usia dini tidak dapat ditangani secara pidana.

Jika semua orang, terutama orang tua, benar-benar menyadari dan belajar dari berbagai dampak negatif yang ditimbulkan akibat perkawinan anak di bawah umur, dapat dipastikan tidak ada anak-anak di bawah umur, terutama anak perempuan, 
akan menjadi korban dari dampak negatif perkawinan dimaksud.

\section{Telaah Undang-Undang Perlindungan} Anak terhadap Penyimpangan ketentuan

UU No. 1 tahun 1974 tentang batas usia minimal perkawinan

Sebagaimana disebutkan, Undangundang no. 1 tahun 1974 tentang perkawinan tidak menunjukkan batasan yang tegas tentang "kematangan" calon penganten, sehingga calon penganten yang belum "dewasa" pun dapat melangsungkan perkawinan jika diinginkan oleh pihak-pihak yang bersangkutan, dan pengadilanpun dapat memberikan izin kepada mereka untuk menikah.

Undang-Undang No. 23 tahun 2002 tentang Perlindungan Anak, yang datang belakangan, 28 sangat memperhitungkan masalah pendewasaan usia perkawinan. Hal ini terlihat, antara lain, pada prinsip-prinsip yang mendasari pembentukan undangundang ini, yaitu prinsipnon-diskriminasi; prinsip kepentingan terbaik bagi anak, prinsip hak untuk hidup, kelangsungan hidup, dan perkembangan, dan prinsip penghargaan terhadap pendapat anak. ${ }^{29}$

Di dalam undang-undang tersebut dinyatakan bahwa ada beberapa hak anak yang harus dipenuhi, yaitu: a) Hak untuk mendapatkan pendidikan, b) Hak untuk berpikir dan berekspresi, c) Hak untuk menyatakan pendapat dan didengar pendapatnya, d) Hak untuk beristirahat dan memanfaatkan waktu luang, bergaul dengan teman sebaya, bermain, berekspresi, dan berkreasi, dan e) Hak untuk mendapatkan perlindungan. Dalam kaitannya dengan pernikahan anak di bawah umur, kelima hak anak tersebut diatas menjadi terlanggar.

Hak anak untuk mendapatkan perlindungan, sebagaimana disebutkan dalam UU No. 23 tahun 2002, sejalan pula dengan pasal 2 ayat 3 dan ayat 4 UndangUndang Republik Indonesia No. 4 tahun 1979 tentang Kesejahteraan Anak, yang menyebutkan: "Anak berhak atas pemeliharaan dan perlindungan, baik semasa dalam kandungan maupun sesudah dilahirkan. Anak berhak atas perlindunganperlindungan terhadap lingkungan hidup yang dapat membahayakan dan menghambat pertumbuhan dan perkembangannya dengan wajar". 30

Oleh karena itu, sudah menjadi kewajiban orang tua untuk melindungi anakanaknya, mendidik, bahkan menafkahinya sampai ia dewasa. Anak mestinya dilindungi dari hal-hal yang membawa dampak negatif pada perkembangannya, baik fisik maupun psikhis.Dengan perkawinan dibawah umur, perlindungan orang tua yang tulus dan sejati menjadi berkurang karena beralih kepada suami.Anak seharusnya dilindungi dari pernikahan dini yang berdampak pada perkembangannya, baik secara fisik maupun psikis.

Undang-undang No. 23 tahun 2002 tentang Perlindungan Anak sudah memuat 
ancaman pidana bagi pelanggarnya. Dalam permasalahan pernikahan anak dibawah umur, dalam pasal 82 UU No. 23 tahun 2002 dinyatakan bahwa barangsiapa melakukan bujuk rayu, tipu muslihat, serangkaian kebohongan, atau membujuk anak untuk melakukan atau membiarkan dilakukannya perbuatan cabul, maka dapat dijerat pidana penjara 3 (tiga) sampai 15 (lima belas) tahun dan denda paling banyak Rp. 300.000.000,(tiga ratus juta rupiah) dan paling sedikit Rp. 60.000.000,- (enam puluh juta rupiah).

Dengan demikian, Undang-Undang No. 23 tahun 2002 tentang Perlindungan Anak sudah cukup tegas memberikan sanksi bagi pelanggarnya. Akan tetapi, persoalannya tidak sesederhana yang disebutkan, karena dalam pelaksanaannya, berbagai unsur akan turut tarik menarik kepentingan.

\section{Telaah medis tentang pernikahan usia muda}

Pada umumnya, berbagai kalangan menilai negatif tentang pernikahan anak di bawah umur, karena disinyalir menyebabkan Angka Kematian Ibu melahirkan (AKI) meningkat secara signifikan. Data statistik menunjukkan bahwa angka kematian ibu (AKI) pasca natal di Indonesia merupakan ranking tertinggi dibanding dengan Negaranegara lain di ASEAN. Di Malaysia, angka tersebut hanya mencapai 39 kasus untuk 100.000 persalinan, sementara di Indonesia mencapai 307 kasus untuk 100.000 persalinan. ${ }^{31}$

Pernikahan dini juga berkorelasi positif dengan meningkatnya angka kehamilan yang tidak diinginkan, aborsi, perdagangan manusia (trafficking), jumlah anak telantar, serta meningkatnya angka perceraian dan pengangguran. ${ }^{32}$

Dari aspek kesehatan, ketua Satgas Perlindungan Anak Ikatan Dokter Anak Indonesia (IDAI), DR Rahmat Sentika, menganjurkan masyarakat Indonesia untuk segera menghentikan kebiasaan kawin muda, karena secara medis anak perempuan usia di bawah 16 tahun masih dianggap belum matang secara seksual karena organ reproduksinya baru mengalami menstruasi sehingga tidak dianjurkan untuk menikah. ${ }^{33}$

Beberapa resiko pernikahan usia muda, baik secara psikis, kesehatan reproduksi, serta keselamatan ibu dan bayi yang menjadi taruhan, antara lain: ${ }^{34}$ a) Kurangnya perawatan selama hamil dan sebelum melahirkan, b) Mengalami pendarahan, c) Hipertensi, d) Kelahiran premature, e) Depresi pasca melahirkan, f) Keguguran, g) Anemia kehamilan, h) Keracunan kehamilan (Gestosis).

Mengingat efek negatif dari perkawinan usia muda bagi perempuan ditinjau dari aspek medis, sebagaimana dijelaskan diatas, dapat dipahami bahwa konsep kedewasaan untuk melangsungkan perkawinan harus diperhatikan dan diprioritaskan ketimbang keinginan ataupun 
ego kedua calon mempelai maupun ego orang tua.

\section{Analisis}

Permasalahan-permasalahan yang terjadi terkait pernikahan di bawah umur, memperlihatkan bahwa dari segi substansi hukum tidak memadai bagi anak-anak, khususnya perempuan, untuk mencapai tujuan perkawinan, yaitu memperoleh “keluarga yang bahagia, dan kekal." 35 Karena ketika diimplementasikan, ketentuan hukum yang sangat longgar rentan sekali menimbulkan penafsiran-penafsiran yang keluar dari substansi hukum tersebut. Oleh karena itu, untuk menentukan solusi hukum di masa yang akan datang, di samping permasalahan-permasalahan yang diungkapkan di atas, perlu dikaji beberapa aspek sebagai bahan pertimbangan, antara lain adalah:

\section{a. Aspek Yuridis}

Lembaga perkawinan dalam perspektif Islam adalah lembaga yang sakral. Ikatan perkawinan tersebut diibaratkan sebagai katan yang kuat (mitsaqan ghalizhan) yang bertujuan untuk membentuk keluarga yang sakinah mawaddah wa rahmah. Tujuan ini juga diakomodir di dalam pasal 1 ayat 1 UU No.1 tahun 1974: "Perkawinan adalah ikatan lahir batin antara seorang pria dan seorang wanita sebagai suami istri dengan tujuan membentuk keluarga (rumah tangga) yang kekal berdasarkan Ketuhanan Yang Maha Esa."

Di dalam ketentuan agama (Islam) memang tidak ada batas umur minimal untuk perkawinan.Yang disyaratkan adalah baligh atau dewasa. Karena kedewasaan tidak sama diantara satu anak dengan yang lainnya, maka batas umur tersebut menjadi elastis.

Penentuan batas umur di dalam UU No. 1 tahun 1974 maupun dalam Kompilasi Hukum Islam di Indonesia memang bersifat ijtihadiyah, sebagai upaya pembaharuan pemikiran fikih masa lampau. Akan tetapi, jika dilacak, referensi syar'iynya mempunyai landasan yang kuat. Umpamanya isyarat Allah SWT dalam surat An-Nisa' ayat 9:

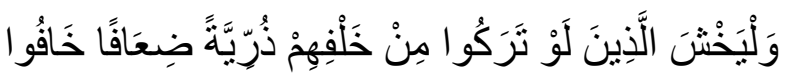

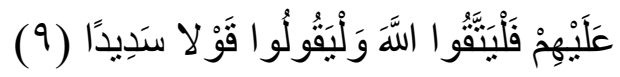

"Dan hendaklah takut kepada Allah orang-orang yang seandainya meninggalkan di belakang mereka anak-anak yang lemah, yang mereka khawatir terhadap (kesejahteraan) mereka.Oleh sebab itu, hendaklah mereka bertakwa kepada Allah dan hendaklah mereka mengucapkan perkataan yang benar."

Ayat tersebut memang bersifat umum, tidak secara langsung menunjuk bahwa perkawinan anak di bawah umur akan meninggalkan keturunan yang dikhawatirkan kesejahteraannya. Akan tetapi, berdasarkan pengamatan dari berbagai pihak, rendahnya usia perkawinan lebih banyak menimbulkan hal-hal yang 
tidak sejalan dengan tujuan perkawinan, yaitu membentuk keluarga yang bahagia dan kekal. Tujuan tersebut akan sulit terwujud jika masing-masing pasangan belum matang (dewasa) fisik dan mentalnya. Kematangan dan integritas pribadi yang stabil akan sangat berpengaruh dalam menyelesaikan setiap problem yang terjadi di dalam keluarga. Banyak kasus menunjukkan hal tersebut. Umpamanya di Pengadilan Agama di Jawa Tengah menunjukkan bahwa banyaknya perceraian cendrung didominasi akibat perkawinan di usia muda. ${ }^{36}$

Rasulullah saw sesungguhnya sudah mengisyaratkan syarat utama untuk melangsungkan perkawinan, yaitu kesanggupan. Hal tersebut ditemukan dalam hadits yang diriwayatkan dari 'Abdullah bin Mas'ud, Rasulullah s.a.w. bersabda: ${ }^{37}$

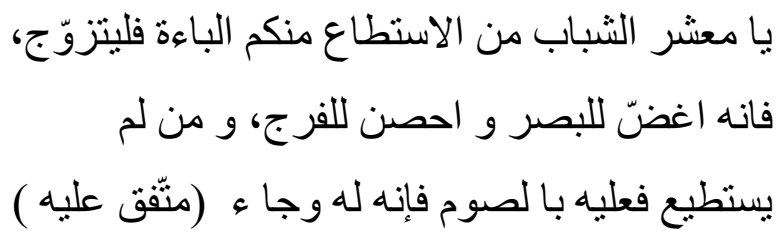

"Hai para pemuda, barangsiapa diantara kamu yang sudah sanggup untuk kawin maka kawinlah, karena hal ituakan menjadi obat dan menahan pandangan dan memelihara kemaluan. Barang siapa yang tidak sanggup maka hendaklah ia berpuasa, karena puasa dapat menjadi benteng" (Muttafaq 'Alaih)

Dalam hadits tersebut ada persyaratan untuk dapat melangsungkan perkawinan, yaitu kesanggupan. Kesanggupan dapat berupa kesanggupan fisik dan mental. Jika dikaitkan dengan perkawinan anak yang belum matang secara fisik dan mentalnya, jelas persyaratan tersebut belum mereka miliki, maka solusinya mereka harus menahan diri terlebih dahulu (berpuasa), sebagaimana yang dianjurkan Rasulullah saw.

Memang, dalam pandangan imam mazhab, seperti Syafi'I, Maliki, Hanbali, dan Hanafi, menikahkan anak yang belum dewasa itu dibolehkan.Hal ini dikaitkan dengan adanya hak ijbar, yaitu hak ayah atau kakek untuk mengawinkan anak perempuannya, baik yang sudah dewasa maupun yang masih belia tanpa harus mendapatkan persetujuan dan izin terlebih dahulu dari anak perempuan tersebut, asalkan anak perempuan itu tidak berstatus janda. ${ }^{38}$

Menurut fuqaha yang lain, seperti Ibnu Syubrumah, Abu Bakr al-Asham, dan Utsman al-Batti, laki-laki dan perempuan yang masih dibawah umur tidak sah dinikahkan. Mereka hanya boleh dinikahkan setelah baligh dan melalui persetujuan yang bersangkutan secara eksplisit. Alasan yang mereka gunkan adalah firman Allah dalam surat An-Nisa' ayat 6:

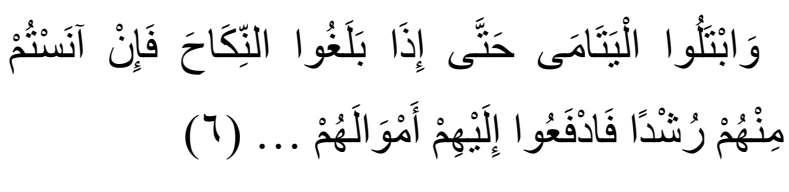

"dan ujilah anak yatim itu sampai mereka cukup umur untuk kawin, kemudian jika menurut pendapatmu mereka telah cerdas (pandai memelihara harta), maka serahkanlah kepada mereka harta-hartanya..." (QS. 4: 6) 
Berdasarkan ayat ini, menurut ketiga ulama diatas, jika anak-anak yang belum baligh boleh dinikahkan, maka ayat ini tidak memiliki nilai fungsi. Ibnu Syubromah menyatakan bahwa agama melarang perkawinan anak sebelum usia baligh. Menurutnya, nilai esensial perkawinan adalah memenuhi kebutuhan biologis dan melanggengkan keturunan. Sementara dua hal ini tidak terdapat pada anak yang belum baligh. Ia lebih menekankan pada tujuan pokok perkawinan. Ibnu Syubromah mencoba melepaskan diri dari kungkungan teks, dan memahami masalah ini dari aspek historis, sosiologis dan kultural yang ada, sehingga dalam menyikapi perkawinan Nabi Muhammad s.a.w. dengan Siti A'isyah yang saat itu berusia usia 6 tahun, 39 Ibnu Syubrumah menganggap sebagai pengecualian dan ketentuan khusus bagi Nabi Muhammad s.a.w. yang tidak bisa diberlakukan bagi umatnya. 40

Dari penjelasan diatas dapat dipahami bahwa pada prinsipnya kedewasaan untuk melangsungkan perkawinan menurut Islam sangat ditekankan demi tercapainya tujuan perkawinan, meskipun agama juga tidak menentukan batas umur yang pasti. Dalam hal ini, diserahkan kepada masyarakat untuk menentukannya sendiri, asalkan tidak menimbulkan kemudharatan, dan asalkan menjamin terwujudnya keluarga yang sakinah dan tentram dalam keadilan. Dalam kaitan ini, sudah sepatutnya para ulama dan umara di Indonesia memperhatikan konsep istishlah dan sadd al-dzari'ah dalam penetapan hukum terkait usia pernikahan.

Istishlah adalah sesuatu yang dipandang baik oleh akal sehat karena mendatangkan kebaikan dan menghilangkan keburukan (kerusakan) bagi manusia, sejalan dengan tujuan syara' dalam menetapkan hukum. ${ }^{41}$ Sadd al-dzari'ah, menurut Ibn Qayyim,adalah menutup apa-apa yang menjadi perantara dan jalan kepada sesuatu. ${ }^{42}$

\section{b. Aspek Sosiologis}

Suatu ketentuan hukum harus dapat tumbuh dan berkembang ditengahtengah masyarakat, diterima oleh masyarakat dengan baik, dan tak kalah pentingnya dapat memberikan kemashlatan untuk seluruh masyarakat baik laki-laki, perempuan, anakanak maupun dewasa. Oleh karena itu agar suatu peraturan perundang-undangan itu dapat diterapkan di dalam masyarakat perlu dilakukan sosialisasi secara komprehensif dan menyeluruh agar berbagai aspirasi yang berkembang di tengah-tengah masyarakat dapat diakomodir dalam rancangan peraturan yang akan dibuat tersebut.

Rumusan suatu peraturan perundang-undangan yang dihasilkan tidak akan berarti jika tidak dapat diterima masyarakat. Disinilah signifikansi suatu peraturan perundang-undangan dilihat dari aspek sosiologis. Apalagi masalah perkawinan merupakan masalah yang sakral 
dan akan berkaitan dengan kemashlatan orang-orang yang berada dalam perkawinan; suami, istri dan anak-anak yang dilahirkan serta keluarga besar kedua belah pihak.

\section{c. Aspek Filosofis}

Sesungguhnya syari'at (hukum) Islam tidak memiliki tujuan lain kecuali untuk mewujudkan kemashlatan kemanusiaan yang universal (jalb al-mashlih) dan menolak segala bentuk kemafsadatan (dar'u almafasid). Ibn al-Qayyim al-Jauziyah, seorang tokoh Islam bermadzhab Hanbali, menyimpulkan bahwa syari'at Islam dibangun untuk kepentingan manusia dan tujuan-tujuan kemanusiaan universal, yaitu kemashlatan (al-mashlahat), keadilan (al-'adl), kerahmatan (al-rahmat), dan kebijaksanaan (al-hikmah). Prinsip-prinsip ini haruslah menjadi dasar dan substansi dari seluruh persoalan hukum Islam.Ia harus senantiasa ada dalam pikiran para ahli fikih ketika memutuskan suatu kasus hukum.

Penyimpangan terhadap prinsipprinsip ini berarti menyalahi cita-cita hukum Islam. Persoalannya, jika acuan hukum adalah kemashlatan, maka siapa yang berhak mendefinisikan dan yang memiliki otoritas untuk merumuskannya? Untuk menjawabnya, perlu dibedakan antara kemashlatan yang bersifat individual (subyektif) dan kemashlatan yang bersifat sosial (obyektif). Yang pertama adalah kemaslahatan yang menyangkut kepentingan orang per orang yang terpisah dengan kepentingan orang lain. Penentu kemashlatan pertama ini adalah orang yang bersangkutan. Jenis kemashlatan kedua adalah kemashlatan yang menyangkut kepentingan orang banyak. Otoritas yang memberikan penilaian adalah orang banyak melalui mekanisme syura untuk mencapai konsensus (ijma'). Sesuatu yang telah menjadi konsensus dari proses pendefinisian maslahat melalui musyawarah itulah hukum tertinggi yang mengikat. Di sinilah pemecahan masalah bersama cukup menentukan. Al-Qur'an mengatakan, urusan mereka dimusyawarahkan (dibicarakan dan diputuskan) bersama di antara mereka sendiri. (QS.:al-Syura,38).

\section{KESIMPULAN}

Ketidaktegasan undang-undang dalam menentukan batas usia perkawinan berimplikasi terhadap pelaksanaannya di dalam masyarakat. Apalagi di dalam keyakinan agama yang dianut masyarakat juga tidak ditentukan secara tegas.

Mengingat tujuan perkawinan yang luhur, batas usia untuk melangsungkan perkawinan perlu ditegaskan oleh undangundang, yaitu 21 tahun bagi pria dan 19 tahun bagi wanita (merevisi pasal 7 ayat 1 yang menyebutkan 19 tahun bagi pria dan 16 tahun bagi wanita). Tidak perlu ada dispensasi terhadap hal tersebut seperti yang disebutkan dalam pasal 7 ayat 2 dan 3. Batas usia tersebut ditentukan berdasarkan berbagai pertimbangan, sebagaimana sudah dipaparkan. 
Tidak kalah pentingnya harus diperhatikan adalah pendidikan yang cukup bagi kedua calon pengantin. Calon pengantin yang mempunyai pendidikan dan wawasan yang cukup akan sangat berpengaruh terhadap kualitas perkawinan dan kualitas keturunan yang akan dihasilkan dari perkawinan tersebut.

Melangsungkan pernikahan di bawah batas usia yang telah ditentukan oleh undang-undang berarti pelanggaran terhadap hukum atau perundang-undangan yang berlaku. Akan tetapi, sanksi bagi pelanggaran tersebut tidak diatur sama sekali di dalam undang-undang. Inilah kelemahan hukum keluarga di Indonesia pada umumnya, dan khususnya hukum perkawinan, sehingga banyak terjadi penyimpangan-penyimpangan. Sanksi terhadap pelanggar perlu ditegaskan, sebagaimana undang-undang lain, agar setiap ketentuan dalam undang-undang tidak hanya seolah secarik acuan bagi hakim untuk memutuskan perkara di pengadilan “jika ada yang mau berperkara". Selebihnya, undang-undang ini seolah tidak bertujuan mengayomi dan menciptakan ketentraman dan keadilan dalam masyarakat, seperti apa yang diperjuangkan sebelum undangundang ini dibentuk.

$$
\text { Sosialisasi tentang tujuan }
$$

diberlakukannya undang-undang, serta maslahat dan mafsadat yang ditimbulkan dari perkawinan usia muda, perlu dilakukan secara terus menerus kepada masyarakat untuk memberikan pemahaman yang lebih baik dan mengayomi pihak-pihak yang lemah dalam perkawinan usia muda tersebut.

Anggapan sebagian kalangan bahwa perkawinan sebagai masalah individu dan cukup dilakukan dengan aturan-aturan agama sudah saatnya diubah.Pemerintah sebagai pemegang otoritas kekuasaan, melalui peraturan perundang-undangan, sangat dibutuhkan campur tangannya dalam mengurus masalah perkawinan karena perkawinan adalah masalah sosial (hablum min al-naasi) yang sangat berpengaruh terhadap ketentraman dan keteraturan masyarakat.

\section{Endnotes}

1 Undang-undang sebagai hasil ijtihad kolektif (jama'i) dinamikanya relatif lamban.Karena biasanya untuk mengubah suatu undangundang memerlukan waktu, biaya, persiapan yang tidak sedikit. Tidak setiap negara muslim memiliki produk pemikiran hukum jenis undang-undang ini. Umpamanya Saudi Arabia, belum dijumpai adanya undangundang, karena mereka merasa cukup dengan ketentuan syari'ah, atau dalam batas-batas tertentu fiqh.Barulah belakangan mereka membentuk lembaga legislatif. Tetapi Negaranegara muslim lain seperti Yordania, Irak, Mesir, al-Jazair, termasuk Indonesia, memiliki undang-undang sebagai peraturan organik tentang masalah tertentu. Lihat Tahir Mahmood, Personal Law in Islamic Countries, (New Delhi: Academy of Law and Religion, 1987), hal. 8

2 Lihat Daniel S.Lev, Peradilan Agama di Indonesia, alih bahasa Zaini amhad Noeh, (Jakarta: Intermasa, 1980), hal. 32-34

3 Arso Sosroatmodjo dan A. Wasit Aulawi, Hukum Perkawinan di Indonesia, (Jakarta: Bulan Bintang, 1978), hal. 9 
4 Muhammad Daud Ali, Hukum Islam dan Peradilan Agama, (Jakarta: PT Raja Grafindo Persada, 1997), hal. 21

5 Usaha tersebut juga terlihat dengan dilangsungkannya Musyawarah Pekerja Sosial (1960), Musyawarah Kesejahteraan Keluarga (1960), Konferensi Badan Penasihat Perkawinan, Perselisihan dan Perceraian (BP4) Pusat, dan Seminar Hukum oleh Persatuan Sarjana Hukum Indonesia (PERSAHI, 1963).

6 Arso Sosroatmojo, op. cit., hlm. 11

7 Undang-undang No. 1 tahun 1974 tentang Perkawinan tersebut terdiri dari 14 bab dan 67 pasal.Isi masing-masing bab itu secara garis besar adalah: Bab I: Dasar perkawinan. Bab II: Syarat-syarat perkawinan, Bab III: Pencegahan perkawinan, Bab IV: Batalnya perkawinan, Bab V: Perjanjian perkawinan, Bab VI : Hak dan kewajiban suami istri. Bab VII: Harta benda dalam perkawinan. Bab VIII: Putusnya perkawinan serta akibatnya. Bab IX: Kedudukan anak. Bab X: Hak dan kewajiban antara orang tua dan anak, Bab XI: Perwalian, Bab XII : Ketentuan-ketentuan lain. Bab XIII: Ketentuan Perwalian. Bab XIV: Ketentuan Penutup

8 Menurut Khoiruddin Nasution, keburukan itu antara lain a. suami berhak menahan isteri untuk tetap di rumah; $b$. isteri wajib patuh kepada suami; c. suami berhak memberikan pelajaran kepada isteri; d. isteri wajib memenuhi kebutuhan seks suami. Lihat: Khoiruddin Nasution, Tentang Relasi Suami dan Isteri (Hukum Perkawinan I) Dilengkapi dengan Perbandingan UU Negara Muslim (Yogyakarta: Academia-Tazzafa, 2004), Hal. 285

9 Arso Sosroatmodjo, op. cit, Hal. 9

10 Pasal 1 UU No. 1 Tahun 1974 dan Pasal 1 Permendagri No. 12 Tahun 2010.

11 Ahmad Rofiq, op. cit., hlm. 57. Lihat juga Penjelasan Umum UU No. 1 tahun 1974 jo. Peraturan Pemerintah No. 9 tahun 1975 tentang Perkawinan, (Jakarta, Pradnya Paramita, , 1977), Hal. 28-29 sub 4.

12 Kompilasi Hukum Islam di Indonesia, (Bandung: Humaniora Utama Press, 1992)
${ }^{13}$ Ahmad Rofiq, op. cit., Hal. 77

${ }^{14}$ Aturan tentang batas umur perkawinan juga diatur di dalam KUH Perdata, pasal 28, disebutkan bahwa seorang jejaka yang belum mencapai umur genap 18 tahun, sebagaimana seorang gadis yang belum mencapai umur genap 15 tahun, tidak diperbolehkan mengikatkan diri dalam perkawinan. Bagi bangsa Indonesia yang beragama Kristen, masalah usia perkawinan bagi mereka diatur dalam Ordonansi Perkawinan Indonesia Kristen (HOCI) yang menyebutkan bahwa pemuda yang umurnya belum cukup 18 tahun dan pemudi yang umurnya belum cukup 15 tahun tidak boleh menikah (pasal $4 \mathrm{HOCI}$ ). Lihat Djoko Prakoso dan I Ketut Murtika, Azas-azas Hukum Perkawinan di Indonesia, (Jakarta: Bina Aksara, 1987), Hal. 18

${ }^{15}$ Undang-undang nomor 23 tahun 2002 tentang Perlindungan Anak menyatakan secara tegas bahwa anak adalah seseorang yang belum berusia 18 (delapan belas) tahun, termasuk anak yang masih dalam kandungan (Pasal 1) dan pada pasal 26 ayat 1 poin c disebutkan bahwa keluarga dan orang tua berkewajiban untuk mencegah terjadinya perkawinan di usia anak-anak. Secara jelas undang-undang ini mengatakan, tidak seharusnya pernikahan dilakukan terhadap mereka yang usianya masih di bawah 18 tahun.

${ }^{16}$ Djoko Prakoso dan I Ketut Murtika, op, cit., hlm. 56

${ }^{17}$ Ibid.

${ }_{18}$ Masalah izin orang tua bagi anak dibawah umur, juga berlaku bagi orang-orang Tionghoa dan Eropa, sebagaimana diatur dalam pasal 9 dan 10 Stbld.1933.

19 Djoko Prakoso dan I Ketut Murtika, op. cit., Hal. 57

${ }^{20}$ Dapat dilihat kasus pernikahan Syekh Puji yang pernah menyita perhatian. khabarislam.wordpress.com. menulis: "Pernikahan Syekh Puji dengan Luthfiana Ulfa yang dilaksanakan pada bulan Agustus 2008 menuai kontroversi. Adanya pihak-pihak luar dari kedua belah pihak yang menginginkan pembatalan pernikahan tersebut dengan alasan secara UU (hukum-hukum positif negara ini) pernikahan tersebut tidak sah 
karena terjadi terhadap anak dibawah usia 18 tahun.

21 http://cetak.kompas.com/read/xml/2009/01 /29/01050780/pernikahan.dini.melanggar.hm

22 Siti Musdah Mulia, dalam Diskusi "Pernikahan Anak di Bawah Umur dalam Perspektif Perlindungan Anak", Jakarta, 28 Maret 2009

23 Data Populasi Nias dan Nias Selatan, BPS Tahun 2005. Ahmad Sofian, MA dan Misran Lubis - Tim PKPA (Pusat Kajian dan Perlindungan Anak).

24 Ahmad Sofian, MA dan Misran Lubis, op. cit.

25 Data Populasi Nias dan Nias Selatan, BPS Tahun 2005.

26 Ibid.

${ }^{27}$ BCZ Online/Kamis, 30 Oktober 2008

28 Sebelum kelahiran Undang-Undang No. 23 tahun 2002 tentang Perlindungan Anak, Indonesia telah memiliki beberapa undangundang yang melindungi hak-hak anak, yaitu: pasal 20, pasal 20A ayat (1), pasal 21, pasal 28B ayat (2), dan pasal 34 UUD RI tahun 1945; UU No. 4 tahun 1979 tentang Kesejahteraan Anak; UU No. 7 tahun 1984 tentang Penghapusan Segala Bentuk Diskriminasi terhadap Perempuan (Convention on the Elimination of All Forms of Discrimination Agains Woman); UU No. 3 tahun 1997 tentang Pengadilan Anak; UU No. 4 tahun 1997 tentang Penyandang Cacat; UU No. 20 tahun 1999 tentang Pengesahan ILO Convention No. 138Concerning Minimum Age for Admission to Employment; UU No. 39 tahun 1999 tentang Hak Azasi Manusia;UU No. 1 tahun 2000 tentang Pengesahan ILO Convention No. 182 Concerning the Prohibition and Immediate for the Elimination of the Worst Forms of Child Labour. Kementrian Pemberdayaan Perempuan RI dan Departemen Sosial RI, Undang-Undang Republik Indonesia Nomor 23 tahun 2002 tentang Perlindungan Anak, Hal. 10-12.

29 Lihat pasal 2 UU no. 23 tahun 2002 tentang Perlindungan Anak.

${ }^{30}$ Arif Gosita, Masalah Perlindungan Anak, (Jakarta: CV Akademika Pressindo, 1987), Hal. 17

${ }^{31}$ Badan Pusat Statistik tahun 2003, dikutip dari Zaitunah Subhan, Menggagas Fiqh
Pemberdayaan Perempuan, (Jakarta: el-Kahfi, 2008), Hal. 222

32 http://cetak.kompas.com/read/xml/2009/01/ 29/01050780/pernikahan.dini.melanggar.ham

33 Ibid.

34 http://masiahonly-chiinges.blogspot. com/ 2012/05/bahaya-pernikahan-dini-hamilusia.html

${ }^{35}$ Sesuai dengan pasal 1 UU No. 1 tahun 1974

36 Ahmad Rofiq, op.cit., Hal. 78

37 Al-Shan'aniy, Subul al-Salam, Juz 3, (Kairo: Dar al-Ihya' al-Turats al-'Arabiy, 1980), Hal., 109

38 Zaitunah Subhan, Menggagas Figh Pemberdayaan Perempuan, (Jakarta: el-Kahfi, 2008), Hal. 219

39 Ibn Hazm, Al-Muhalla, Juz 9, hlm. 459, dikutip oleh Husein Muhammad, "Fiqh Perempuan Refleksi Kiai atas Wacana Agama dan Jender", (Yogyakarta: LKIS, 2001), Hal. 70-72

40 Ibrahim, al Bajuri, vol. 2 (Semarang: Toha Putra, 1992), Hal. 90

41 Untuk lebih jelasnya tentang konsep Maslahah ini baca a.l. Wahbah al-Zuhaili, Ushul al-Figh al-Islam, (Damaskus: Dar al-Fikr, 1968), hlm. 756- 793; Amir Syarifuddin, Ushul Figh, jilid 2, (Jakarta: Kencana, 2009), Hal. 345-363.

42 Baca selengkapnya Wahbah al-Zuhaili, Ibid., Hal. 902-942

\section{DAFTAR PUSTAKA}

Ahmad Rofiq, Hukum Islam di Indonesia, Jakarta: PT RajaGrafindo Persada, 1995

Ahmad Sofian, MA dan Misran Lubis - Tim PKPA (Pusat Kajian dan Perlindungan Anak)

Al-Shan'aniy, Subul al-Salam, Juz 3, Kairo: Dar al-Ihya' al-Turats al-'Arabiy, 1980

Amir Syarifuddin, Ushul Figh, jilid 2, Jakarta: Kencana, 2009 
Arif Gosita, Masalah Perlindungan Anak, Jakarta: CV Akademika Pressindo, 1987

Arso Sosroatmodjo dan A. Wasit Aulawi, Hukum Perkawinan di Indonesia, Jakarta: Bulan Bintang, 1978

BCZ Online/Kamis, 30 Oktober 2008

Daniel S.Lev, Peradilan Agama di Indonesia, alih bahasa Zaini amhad Noeh, Jakarta: Intermasa, 1980

Data Populasi Nias dan Nias Selatan, BPS Tahun 2005

Djoko Prakoso dan I Ketut Murtika, Azas-azas Hukum Perkawinan di Indonesia, Jakarta: Bina Aksara, 1987

http:/ / cetak.kompas.com/read/xml/2009/0 1/29/01050780/pernikahan.dini.mela nggar.ham

http:/ / masiahonlychiinges.blogspot.com/2012/05/baha ya-pernikahan-dini-hamil-usia.html

Ibn Hazm, Al-Muhalla, Juz 9, hlm. 459, dikutip oleh Husein Muhammad, "Fiqh Perempuan Refleksi Kiai atas Wacana Agama dan Jender", Yogyakarta: LKIS, 2001

Ibrahim al-Bajuri, al Bajuri, vol. 2, Semarang: Toha Putra, 1992

khabarislam.wordpress.com.

Khoiruddin Nasution, Tentang Relasi Suami dan Isteri (Hukum Perkawinan I) Dilengkapi dengan Perbandingan UU Negara Muslim, Yogyakarta: Academia-Tazzafa, 2004

Kompilasi Hukum Islam di Indonesia, Bandung: Humaniora Utama Press, 1992
Muhammad Daud Ali, Hukum Islam dan Peradilan Agama, Jakarta: PT Raja Grafindo Persada, 1997

Penjelasan Umum UU No. 1 tahun 1974 jo. Peraturan Pemerintah No. 9 tahun 1975 tentang Perkawinan, Jakarta, Pradnya Paramita, 1977

Tahir Mahmood, Personal Law in Islamic Countries, New Delhi: Academy of Law and Religion, 1987

Wahbah al-Zuhaili, Ushul al-Figh al-Islam, Damaskus: Dar al-Fikr, 1968

Zaitunah Subhan, Menggagas Figh Pemberdayaan Perempuan, Jakarta: elKahfi, 2008 